\title{
Conceptualizing Conflict Management and Conflict Resolution as Distinct Negotiation Processes in the Context of the Enduring Israeli-Palestinian Conflict
}

\author{
Ruth Ben-Artzi, ${ }^{1}$ Moty Cristal, ${ }^{2}$ and Shirli Kopelman ${ }^{3}$ \\ 1 Department of Political Science, Providence College, Providence, RI, U.S.A. \\ 2 The Israeli Center of Negotiations, Tel-Aviv, Israel \\ 3 Department of Management and Organizations, Ross School of Business, University of Michigan, Ann Arbor, MI, U.S.A.
}

\section{Keywords}

conflict, conflict resolution, conflict management, negotiation process, Israel, Palestine, Israeli-Palestinian conflict, Middle East.

\section{Correspondence \\ Shirli Kopelman, Department of Management and \\ Organizations, Ross School of Business, University of Michigan, 701 Tappan Street Ann Arbor, MI 48109-1234, U.S.A.; e-mail: shirli@umich.edu.}

\begin{abstract}
Negotiations in the Israeli-Palestinian conflict are historically traced and compared through an analysis of conflict resolution (CR) and conflict management (CM), defined as distinct negotiation processes. The assumption that $\mathrm{CM}$ is a stepping-stone to $\mathrm{CR}$ is challenged: Linking the two processes has not only entrenched but exacerbated this enduring conflict. Theoretical and practical implications are discussed.
\end{abstract}

Why are some conflicts difficult to resolve, thus persisting over time? Although disputing parties in enduring rivalries often engage in negotiations, negotiations are not always successful in ending a conflict. In examining the enduring Israeli-Palestinian conflict, we assess the nature of the negotiations that have occurred over the past decades. We look at the types of negotiation processes, specifically whether their objective was the management or the resolution of the conflict. We suggest that categorizing conflict management $(\mathrm{CM})$ and conflict resolution $(\mathrm{CR})$ as distinct negotiation processes helps explain the failure to date to resolve this conflict. Further, we argue that $\mathrm{CM}$ is not a prerequisite for the resolution of conflict nor is it necessarily a stepping-stone on the way to resolution. To the contrary, the IsraeliPalestinian example demonstrates that $\mathrm{CM}$ and its distinct objectives can lead paradoxically to the escalation of conflict, making resolution even harder to attain. Although CR negotiations do not always succeed in bringing about a resolution, they may be more likely to fail when CM is construed as an integral part of the resolution process.

Destructive international conflicts that have endured for more than 20 years, which includes the Israeli-Palestinian conflict, have been referred to as intractable conflicts (Coleman \& Vallacher, 2011), deep-rooted conflict (Burton, 1987), protracted social conflict (Azar, 1986), moral conflict (Pearce \& Littlejohn, 1997), and enduring rivalries (Diehl \& Goertz, 2000). These conflicts are characterized by factors such as legacies of dominance and injustice, instability, human and social polarities, symbolism and ideology, oppositional group identities and intense intragroup dynamics, strong emotionality, protracted trauma, and normalization of hostility (Coleman, Deutsch, \& Marcus, 2014; Goddard, 2010).

To be sure, both Israelis and Palestinians are no strangers to the negotiating table. In fact, they have engaged in frequent negotiations in the last two decades of the conflict, following a period of no direct 
negotiations between 1967 and 1991. The disputed issues in this conflict and what a resolution might look like seem rather clear to many, and yet after many rounds of negotiations a resolution is ever so distant. We contend that the conceptual distinction between CM and CR negotiations helps illuminate the persistence of this conflict. According to Zartman (2007), the study of peacemaking recognizes the inevitability of conflict. At the same time, it presents ways in which "conflict can be first managed, moving from violent to political manifestations, and then resolved, transforming it and removing its causes" (p. 3). Here, we trace the history of the Israeli-Palestinian conflict, explore the attempts of CR and the multiple CM agreements, and then propose that the theoretical assumption that CM leads to CR has stalled, and even further distanced, rather than facilitated the end of this conflict.

\section{Enduring Rivalries: The Israeli-Palestinian Conflict and Failed Attempts at Resolution}

Prior to 1967, the Israeli-Palestinian (I-P) conflict was embedded in the broader Arab-Israeli conflict (Maoz, 2006). Israel became independent in 1948 with the culmination of the British Mandate, and the 1967 Arab-Israeli War marked the transition of Palestinian nationalism from a pan-Arab movement to a nation seeking sovereignty. With Jordan's and Egypt's acquiescence to designate the West Bank, East Jerusalem, and Gaza Strip territories as part of the future Palestinian state, Palestinians became a stateseeking nation. Between 1967 and 1987, there were no direct official talks between Israel and the Palestinians, though the Palestinian issue was an essential element in the 1978 Camp David talks. The 1978 Camp David Accords between Israel and Egypt stipulated neither CM nor CR, but formally acknowledged the need to address the Israeli-Palestinian conflict.

With the outbreak of the First Intifada in 1987, the conflict shifted gears; there were now frequent periods of formal CM and CR negotiation processes in conjunction with increased violence, including violent outbursts originating in the Palestinian Territories - Gaza and the West Bank. The 1987 intifada marked the first time Palestinians from within the West Bank and Gaza used violent means to pursue their political goals in the conflict. Casualties on both sides brought the conflicting parties to recognize that the situation had reached a mutually hurting stalemate (Zartman, 1997). Further, international intervention became more forceful, demanding that negotiations be conducted to resolve the conflict. The First Intifada's violence, in this sense, opened the door to the first attempts of direct negotiations between Israel and Palestinian delegates in Madrid (1991) and Oslo (1993). However, lacking a clear distinction between $\mathrm{CM}$ and $\mathrm{CR}$, parties embarked on three failed negotiation processes following the first intifada: the Madrid Conference of 1991, the Oslo process, which began in 1993, and the 2000 Camp David Summit.

The Madrid talks marked the first time Israeli and Palestinian delegates met openly to negotiate an agreement, and although the talks were fruitless, they opened a door for further discussions by establishing a precedent for CR negotiations. Soon thereafter, more violence erupted, and the negotiation process took the form of CM rather than an attempt at a resolution. The Madrid format was a regional one that included other Arab countries. It followed the logic that a comprehensive regional agreement would facilitate the resolution of the I-P conflict, much like Shimon Peres discussed in his 1993 book, The New Middle East. Peres observed that mutual incentives, such as a common economic market between Israel, Palestinians, and the rest of the region, could be a platform for addressing the conflict. He argued that facilitating regional economic interdependence in the Middle East would naturally lead to cooperation based on countries' dependency on one another for economic stability, thereby creating a well-protected peace treaty. Scholarship on interdependency and its pacifying qualities (e.g., Grieco, 1990; Ruggie, 1993) also supports this notion.

Following this logic, regional cooperation was a central mechanism of the Madrid talks in 1991, when the American-facilitated negotiations attempted to resolve the conflict by tying its resolution to normalization of interstate relations across the region. As these talks took place following the First Intifada, the combination of economic promise and an end to violence presented mutual gains for both parties: For the 
Palestinians, the attainment of an independent Palestinian state and a firm commitment by the international community to help establish and fund political and economic institutions; and for the Israelis, an end to the violence and the normalization of political and economic relations with other countries in the region. The conveners of the talks - particularly the United States - had the explicit goals of capitalizing on the opportunity that had presented itself after a successful regional coalition in the First Gulf War and of reaching a peace settlement. The Israelis and Palestinians may have had different goals. The presumed objective of these talks was a resolution to the I-P conflict; however, they did not lead to an agreement.

The stalemate and violence that followed triggered another attempt to resolve the conflict: the Oslo talks in 1993. The Oslo Accords relied on the notion of the confidence- and security-building measures approach (Holst, 1983; Hunter \& Jones, 2004; Landau \& Landau, 1997; Maoz, 2006; Rittberger, Efinger, \& Mendler, 1990). Instead of discussing the difficult issues at the heart of the conflict, the process suggested that CM would lead to CR by building trust between the parties. The process was designed in stages; after some stages of CM were accomplished, CR negotiations would ensue because the parties would be more confident in each other's intention to resolve the most difficult aspects of the conflict. Unlike the Madrid talks, Oslo was limited to both sides (Israelis and Palestinians) without U.S. mediation and was devised as a lengthier process than one that might have started with CR negotiations. However, countless violations on both sides and continued violence derailed the process, and negotiations for resolution never took place despite a comprehensive CR draft agreement reached in track II by Yossi Beilin and Abu Mazen in 1995.

The next attempt at CR, the 2000 Camp David Summit, marked a change in approach. This time a resolution to the conflict was explicitly laid out before any stages were discussed. However, the pressures of a U.S. administration on its way out and an Israeli prime minister under threat of the dissolution of his government caused the Americans and the Israelis to adopt a hurried approach. The politically motivated timing of these negotiations was seriously compromising; along with Arafat's decline in popularity, this situation presented a conundrum for the Palestinians. The appearance that the Palestinians would accept an agreement drafted by the United States and Israel, whether justified or not, was politically unacceptable to the Palestinian Authority. It symbolically emphasized the power imbalance between the negotiating parties. However, the post hoc assertion that Camp David failed because the timing was wrong - or the moment was not ripe-is functional, because had CR succeeded at Camp David, the historical moment would have been interpreted as ripe (Cristal, 2012).

The substantive framework for CR in the 2000 Camp David negotiations was pragmatic and could have yielded the desired results. Multiple reasons have been identified for its failure (Malley \& Agha, 2001). One negotiation-process mistake may have been that by insisting that the permanent status agreement would be dubbed a final offer and mark the finality of claims to the Israeli-Palestinian conflict, Israel's position could have been interpreted by the Palestinians as an ultimatum. At the end, Barak's intimidating power-move facilitated a reciprocal power-move by the Palestinians, culminating in the Second Intifada, which erupted following opposition leader Ariel Sharon's controversial visit to the Temple Mount. Another ground for the failure of the 2000 Camp David Summit can be explained by mistaking the timing of the talks as a mutually enticing opportunity in the shadow of imminent Israeli and U.S. elections. President Clinton and Prime Minister Barak considered this timing to be a sufficient opportunity for Chairman Arafat, whom they pressured into meeting, even though Arafat urged them to delay the summit. According to Pundak (2001), Arafat preferred to continue with secret negotiations and to try to reach a joint agreement with no outside pressure, leaving a few undecided issues to be discussed later. Despite Arafat's preferences, both Barak and Clinton followed personal incentives to rush into a summit meeting. The short time frame added to the looming pressure, and despite painstaking efforts, no agreement was reached.

After nine years that included three distinct attempts to resolve the ongoing Israeli-Palestinian conflict, the eruption of the Second Intifada on September 29, 2000, marked the end of a CR phase that had begun with the 1991 Madrid talks. The failed peace talks, along with a mix of bad-faith implementations, 
high-risk agreements, poor mediation efforts, and leaders who often had to cater to particular domestic constituencies, redirected subsequent negotiations into a phase of $\mathrm{CM}$, when, instead of seeking a solution, the goals became reactionary, dealing with issues that needed to be addressed immediately. In January 2001, in a fraught effort to salvage CR, negotiators met in Taba, Egypt. For many, this marked the last chance for a resolution before a hawkish Israeli government was expected to come into power. The Taba talks were conducted only days before Barak was expected to-and did-lose an election, and thus they ended inconclusively due to these domestic constraints. In short, although to some it may have seemed that an opportune moment for a resolution had arrived, this was not the case.

Identifying the ripe moment (Zartman, 2000) is complicated by the fact that conflicting parties do not necessarily know when they have reached their limits and a willingness to negotiate and compromise. In prolonged conflicts, political actors who have grown accustomed to the conflict may prefer the known reality of a low-grade and mostly managed conflict to negotiating a resolution-an unknown, risky endeavor. Power-based explanations demonstrate that inflicting hurt can change actors' preferences and help bring them to the negotiation table (Jervis, 1999). However, the perceived imbalance of power between Israel and the Palestinians may have weakened Israel's sense of urgency to resolve the conflict; Israel may have regarded concessions in a negotiated agreement as a heavy price when the Palestinians had "nothing to offer." For their part, the Palestinians, having persevered for decades in a state of conflict, may have found it harder as time passed to accept an agreement that offered them less than the objectives for which they had been fighting. Furthermore, cultural differences in perceptions of power may have exacerbated the conflict in terms of procedural justice and distributive justice (Alon, 2000; Alon \& Brett, 2007; Axelrod, 1984; Brett, 2014; Kopelman, 2009; Lind \& Tyler, 1988; Lytle, Brett, \& Shapiro, 1999; Schwartz, 1994; Teitel, 2000). For both sides, the reality of living in conflict may create a cycle that hinders a shift in the negotiation process toward CR.

During the ensuing years of CM, the Quartet (US, Russia, EU, UN) weighed in on the conflict, in 2003; its stance was the creation of an independent Palestinian state roughly along the 1967 borders, with East Jerusalem as its capital. This outside involvement, although not constituting CR negotiations, spurred Israel's unilateral withdrawal from the Gaza Strip as a measure of CM and, one can argue, as a way to avoid further CR negotiations (Birnbaum \& Tibon, 2014). Further, in the decade since, multiple outbursts of conflict were each followed by CM. The first Palestinian tahadiya, or cease-fire, in 2003, and the second one, in 2005 were short-lived and controversial among various Palestinian factions who considered the tahadiya a kind of surrender that would not lead to a desired agreement (Abu Nimah, 2005). The tahadiya was violated numerous times by Palestinian factions that did not agree with its provisions; it was eventually abandoned altogether because neither side was able to move beyond the mutual suspicion that a cease-fire was meant only to please the Quartet mediators and that it was a decoy for further enhancing the conflict.

Another failed CR attempt occurred in 2007 following the Annapolis process that started with the Annapolis Conference between Olmert and Abu Mazen, which was mediated by George W. Bush. This was part of the Quartet initiative, and, although in terms of substance it was the most far-reaching proposed agreement, neither party had the political support at home to carry through an agreement that involved the necessary sacrifices. It differed from the former three CR attempts because under the circumstances the consensus seemed to be that the talks would not result in an agreement nor lead to any changes.

Most recently, Secretary of State John Kerry initiated a negotiation effort in the summer of 2013 with international support (O'Donnell, 2013), which collapsed in April 2014. This marked yet another attempt at CR that followed more than a dozen years of iteration between $\mathrm{CM}$ and violent manifestations of the conflict. Its failure had elements that resemble the previous unsuccessful CR negotiations, particularly a reliance on $\mathrm{CM}$ to reach a resolution. In this case, negotiations were not immediately preceded by a bout of violence but instead were pushed for by the United States. Despite the stated CR objective of the talks, confidence-building measures were scheduled for implementation (such as prisoner release by 
Israel and curbing violence by Palestinians) throughout the nine months of negotiations. These interim steps and perceptions about their violations prevented an advance on the core issues of resolving the conflict (Birnbaum \& Tibon, 2014).

\section{Conflict Management as an Obstacle to Conflict Resolution}

The Israeli-Palestinian conflict persists despite multiple and iterative high-level negotiation attempts. Typical to parties engaged in intractable conflict, the Israeli-Palestinian conflict has been characterized by periods of sustained violence (and war), lulls of détente, periods of CM, and failed attempts at CR. Conflict, according to Pruitt and Rubin (1986), is defined as perceived divergence of interests, or a belief that parties' current aspirations cannot be achieved simultaneously. To overcome the interest gap between the conflicting parties, Zartman (2007) suggested a temporal approach, arguing that conflict needs first to be managed before it can be resolved. Whereas Zartman defined CR as a long-term process that removes the causes and manifestations of a conflict, CM leaves the roots of the conflict unresolved and prioritizes the elimination of violent and violence-related means of pursuing the conflict, opening the possibility to work it out at the political level (Chiozza \& Choi, 2003). The epistemology of the stages approach also includes conflict transformation and conflict prevention. This argument states that each stage is connected to the next, and for each to be realized, the preceding stage must be fully stable.

Interaction between Israelis and Palestinians over the last few decades challenges this approach, which implicitly suggests that conflicting actors realize a ripe moment for CR when their interaction is identified either as a mutually enticing opportunity or as a hurting stalemate (Zartman, 2000). It is not clear whether the parties in the I-P conflict ever aligned on a mutually enticing opportunity, such as the vision of Shimon Peres and the perspective of third-party mediators. The two parties did identify mutually hurting stalemates following violent outbursts. However, once CM addressed these outbursts of violence, the actors were further distanced from CR. We suggest that CM in this case obscured the immediate need to resolve the conflict.

Because the objectives of CM and CR are distinct, achieving CM may distance the parties from incentives to resolve the conflict, creating an illusion of stability. When CM removes the violence but leaves the roots of the conflict intact, necessary measures for resolving those root causes can more easily be delayed. And although CM is a temporary solution, parties to the conflict may calculate that alternating between CM and conflict is less costly than the necessitated concessions for reaching CR.

The Israeli-Palestinian CM and CR negotiations have been characterized by the diffusion of the urgency for resolution due to successful sporadic CM. The stage approach of the Oslo Accords demonstrates this: While each stage in the implementation of the agreement was meant to enhance trust and move the sides closer to an agreement, in reality, the Israelis and Palestinians both took advantage of these time lapses to make power plays that might influence the final agreement in their favor. The absence of an agreed-upon resolution at the outset sets the stage for a framework of CM in the form of stages. The process mandated that CR talks on the tough issues be addressed after the confidence-building measures were complete. When for various reasons these stages did not yield the agreed-upon results, both sides exercised power plays, not only violating the CM agreement but also driving the parties further from CR negotiations.

The violent hostilities between Israel and Gaza over the last decade, with the most recent manifestation in the summer of 2014, demonstrate another challenge to the stages approach of CM leading to CR. As Zartman (2007) posited, the purpose of CM is to remove the violence, "leaving [the conflict] to be worked out on the purely political level" (p. 13). However, in the instances of CM that followed violence between Israel and Gaza $(2008-2009,2011)$, the political stage failed to follow the cease-fire agreements; it remains to be seen if this pattern is repeated following the summer of 2014. In the absence of any agreement beyond that of a cease-fire (CM), violence is likely to cycle back, and the conflict to remain a persisting rivalry. 
To summarize, the enduring Israeli-Palestinian conflict demonstrates, through more than two decades of intermittent negotiations, that $\mathrm{CM}$ and $\mathrm{CR}$ are distinct negotiation processes and that the former does not facilitate the latter. Specifically, as demonstrated by the stages approach of the Oslo Accords and the violent outbursts between Israel and Gaza over the last few years, CM may distance conflicting parties from reaching a resolution. Paradoxically, CM may generate an illusion of stability. Even when CM's temporary nature is acknowledged, it may become an attractive alternative to dealing with the root causes of the conflict and permanently ending it.

Our argument sheds further light on the reasons for the failure of CR. Common explanations for unsuccessful CR attempts include (a) one or both parties may not have been interested in reaching an agreement, so the efforts for resolving the situation were in vain, (b) the situation was not ripe enough for the parties to cut a deal, or (c) the time was historically ripe (the opportunity was there), but the negotiation process was poorly managed (Cristal, 2012; Pundak, 2001). Public opinion polls conducted at the end of July 2000, the culmination of a nine-year period in which three CR negotiation processes failed, affirm all three explanations. The Palestinian Center for Policy and Survey Research (PSR) in Ramallah and the Harry S. Truman Research Institute for the Advancement of Peace at the Hebrew University of Jerusalem (Truman Institute) conducted a joint survey of Palestinians and Israelis (PSR \& Truman Institute, 2000). These polls indicated that Israelis thought that "too much was offered" and that Arafat was not courageous - or willing - enough to accept what was offered. At the same time, Palestinians were offended by the rushed nature of the talks, thought that they were asked to agree to a settlement that was not in their interest, and considered the motivation of both Israel and the American mediators as questionable at best given the political exigencies of both Clinton and Barak (Husseini, 2000). It seems then that neither side was truly interested in reaching an agreement. Likewise, the second possibility is aligned with the claim that the timing of the 2000 Camp David Summit was politically enticing for Clinton and Barak but not for Arafat and the majority of Palestinians, who wished to delay it. The third suggestion expands on the second and holds that the American mediation efforts were responsible for mistakes such as openly siding with the Israeli perspective (FMEP Settlement Report, 2000) and failing to take into account central Palestinian interests (Malley \& Agha, 2001).

Conflict resolution negotiations may fail for many reasons. We suggest that conflict management and conflict resolution negotiations are distinct processes and that the assumption that conflict management leads to conflict resolution is a conceptual obstacle, which has not been identified or discussed in the literature. As demonstrated in the Israeli-Palestinian conflict, conflict management negotiations were too often combined with conflict resolution negotiations and failed as stepping-stones to a resolution. Whether considering the Israeli-Palestinian conflict or other conflicts, we suggest that achieving conflict management may hinder the possibility of attaining conflict resolution because it shifts the interests of the parties and changes their mutual interests to resolve the conflict. Because conflict management is easier to achieve than conflict resolution, it may be appealing as it signals an achievement of sorts. However, if conflict management is viewed in the context that we suggest - that conflict management negotiations are distinct in their scope, methods, and objectives from conflict resolution negotiations - then the attainment of conflict management may be understood as an obstacle to conflict resolution. Despite its immediate relief in the form of eliminating violence, conflict management offers only a temporary solution, is not a stepping-stone to conflict resolution, and even possibly sabotages the prospects for resolution, given the illusion of stability that it produces.

\section{References}

Abu Nimah, H. (2005). The hudna no one wants. The Electronic Intifada, November 11.

Alon, I. (2000). Negotiation in Arabic-speaking Islam: A research note. Davis occasional papers, no. 76. Leonard

Davis Institute for International Relations, Hebrew University of Jerusalem, Israel. 
Alon, I., \& Brett, J. M. (2007). Perceptions of time and their impact on negotiations in the Arabic-speaking Islamic world. Negotiation Journal, 23, 55-73. doi:10.1111/j.1571-9979.2007.00127.x

Axelrod, R. (1984). The evolution of cooperation. New York, NY: Basic Books.

Azar, E. E. (1986). International conflict resolution: Theory and practice. Sussex, UK: Wheatsheaf Books.

Birnbaum, B., \& Tibon, A. (2014). The explosive, inside story of how John Kerry built an Israel-Palestine peace plan - and watched it crumble. New Republic. Retrieved from http://www.newrepublic.com/article/118751/ how-israel-palestine-peace-deal-died

Brett, J. M. (2014). Negotiating globally: How to negotiate deals, resolve disputes, and make decisions across cultural boundaries. San Francisco, CA: Jossey-Bass.

Burton, J. (1987). Resolving deep-rooted conflict: A handbook. Lanham, MD: University Press of America.

Chiozza, G., \& Choi, A. (2003). Guess who did what: Political leaders and the management of territorial disputes, 1950-1990. Journal of Conflict Resolution, 47, 251-278. doi:10.1177/0022002703252364

Coleman, P. T., Deutsch, M., \& Marcus, E. (2014). The handbook of conflict resolution: Theory and practice (3rd ed.). San Francisco, CA: Jossey-Bass.

Coleman, P. T., \& Vallacher, R. (2011). The five percent: Finding solutions to (seemingly) impossible conflicts. New York, NY: Perseus Books.

Cristal, M. (2012). Camp David, 2000. In G. O. Faure (Ed.), Unfinished business: Why international negotiations fail (pp. 43-61). Athens, GA: University of Georgia Press.

Diehl, P. F., \& Goertz, G. (2000). War and peace in international rivalry. Ann Arbor, MI: University of Michigan Press.

FMEP Settlement Report. (2000). Sovereignty and territory issues at the heart of the final status talks. January-February. Retrieved from http://www.fmep.org/reports/archive

Goddard, S. E. (2010). Indivisible territory and the politics of legitimacy: Jerusalem and Northern Ireland. New York, NY: Cambridge University Press.

Grieco, J. M. (1990). Cooperation among nations: Europe, America, and non-tariff barriers to trade. Ithaca, NY: Cornell University Press.

Holst, J. J. (1983). Confidence-building measures a conceptual framework. Survival, 25, 2-15. doi:10.1080/ 00396338308442072

Hunter, R. E., \& Jones, S. G. (2004). An independent Palestine: The security dimension. International Affairs, 80, 202-219. doi:10.1111/j.1468-2346.2004.00379.x

Husseini, F. (2000). Failed compromise at Camp David. Le Monde Diplomatique. Retrived from http://mondediplo.com/2000/12/12campdavid

Jervis, R. (1999). Realism, neoliberalism, and cooperation: Understanding the debate. International Security, 24, 42-63. doi:10.1162/016228899560040

Kopelman, S. (2009). The effect of culture and power on cooperation in commons dilemmas: Implications for global resource management. Organizational Behavior and Human Decision Processes, 108, 153-163. doi:1016/j. obhdp.2005.08.003

Landau, D., \& Landau, S. (1997). Confidence-building measures in mediation. Mediation Quarterly, 15, 97-103. doi:10.1002/crq.3900150204

Lind, A. E., \& Tyler, T. R. (1988). The social psychology of procedural justice. New York, NY: Springer.

Lytle, A. L., Brett, J. M., \& Shapiro, D. L. (1999). The strategic use of interests, rights, and power to resolve disputes. Negotiation Journal, 15, 31-51. doi:10.1111/j.1571-9979.1999.tb00178.x

Malley, R., \& Agha, H. (2001). Camp David: The tragedy of errors. New York Review of Books. Retrieved from http://www.nybooks.com/articles/archives/2001/aug/09/camp-david-the-tragedy-of-errors/

Maoz, Z. (2006). Defending the Holy Land: A critical analysis of Israel's security and foreign policy. Ann Arbor, MI: University of Michigan Press.

O'Donnell, C. M. (2013). How the EU can help Kerry with Israeli and Palestinian peace talks. Brookings. Retrieved from http://www.brookings.edu/research/articles/2013/08/07-eu-help-kerry-israel-palestinepeace-talks-odonnell

Pearce, W. B., \& Littlejohn, S. W. (1997). Moral conflict: When social worlds collide. Thousand Oaks, CA: Sage. Peres, S., \& Naor, A. (1993). The new Middle East. New York, NY: Henry Holt \& Company. 
Pruitt, D. G., \& Rubin, J. Z. (1986). Social conflict: Escalation, stalemate, and settlement. New York, NY: Random House.

PSR and Truman Institute. (2000). Israelis and Palestinians support the peace process and reconciliation but are less willing to pay the price than their leaders [Research poll]. Retrieved from http://www.pcpsr.org/en/node/461

Pundak, R. (2001). From Oslo to Taba: What went wrong? Survival: Global Politics and Strategy, 43, $31-45$. doi:10.1080/00396330112331343035

Rittberger, V., Efinger, M., \& Mendler, M. (1990). Toward an East-West security regime: The case of confidenceand security-building measures. Journal of Peace Research, 27, 55-74. doi:10.1177/0022343390027001006

Ruggie, J. G. (Ed.) (1993). Multilateralism matters: The theory and praxis of an institutional form. New York, NY: Columbia University Press.

Schwartz, S. H. (1994). Beyond individualism-collectivism: New cultural dimensions of values. In U. Kim, H. C. Triandis, C. Kagitçibasi, S. C. Choi, \& G. Yoon (Eds.), Individualism and collectivism: Theory, method, and application (pp. 85-119). Thousand Oaks, CA: Sage.

Teitel, R. G. (2000). Transitional justice. New York, NY: Oxford University Press.

Zartman, I. W. (1997). Explaining Oslo. International Negotiation, 2, 195-215. doi:10.1163/15718069720847942

Zartman, I. W. (2000). Ripeness: The hurting stalemate and beyond. In P. C. Stern \& D. Druckman (Eds.), International conflict resolution after the Cold War (pp. 225-250). Washington, DC: National Academies Press.

Zartman, I. W. (Ed.) (2007). Peacemaking in international conflict: Methods and techniques. Washington, DC: United States Institute of Peace Press.

Ruth Ben-Artzi is Assistant Professor of Political Science at Providence College. She has a Ph.D. in Political Science from Columbia University and has held fellowship positions at the Fondation National des Sciences Politiques (Sciences-Po, Paris, France) and the University of Pennsylvania. Ben-Artzi's research focuses on international organizations and their decision-making processes in the context of development, aid, and North-South relations. She teaches international relations and Middle East politics and appears as an expert guest in local media, discussing political developments in the Middle East.

Moty Cristal, is founder of The Israeli Center of Negotiations (ICON), graduated Bar-Ilan Law School (1994) and Harvard Kennedy School of Government (1998). Cristal is currently a faculty member at SKOLKOVO, Moscow's leading business school, as well as a lecturer at the Technion, Interdisciplinary Center in Herzliya, and the Hebrew University of Jerusalem. From 1994 to 2001, Cristal served in various official capacities in Israeli negotiation teams with Jordan and the Palestinians, and he is the founder of NEST group and the CEO of Negotiation Strategies LTD, a global consulting company, which provides complex negotiations and crisis management training, consulting, and operational support to senior executives in the corporate world and governments.

Shirli Kopelman is leading researcher, expert, and educator in the field of negotiations at the University of Michigan's Ross School of Business and the Ford School of Public Policy. She holds a Ph.D. in Management and Organizations and an MS in Organization Behavior from the Kellogg School of Management at Northwestern University. Her research on emotions in negotiations and social dilemmas has been published in scholarly journals, including Organizational Behavior and Human Decision Processes, Journal of Applied Psychology, and Negotiation and Conflict Management Research. Her work has been featured in media outlets such as Bloomberg Businessweek, Forbes, and Harvard Business Review. Shirli Kopelman is author of Negotiating Genuinely: Being Yourself in Business, published in 2014 by Stanford University Press. 